\title{
Oppositines A and B, Sesquiterpene Pyridine Alkaloids from a Sri
}

\section{Lankan Pleurostylia opposita}

\author{
Emily L. Whitson ${ }^{\dagger}$, S.M.V. Damayanthi Mala ${ }^{\ddagger}$, Charles. A. Veltri ${ }^{\dagger}$, Tim S. Bugni $^{\dagger}$, E. Dilip de \\ Silva $\ddagger$, and Chris M. Ireland ${ }^{\star}, \dagger$ \\ Department of Medicinal Chemistry, University of Utah, Salt Lake City, Utah 84112 and Department \\ of Chemistry, University of Colombo, Colombo 03, Sri Lanka
}

\begin{abstract}
Two new sesquiterpene pyridine alkaloids, oppositines A (1) and B (2), have been isolated from the plant, Pleurostylia opposita (Celastraceae), collected in Sri Lanka. The compounds were isolated and purified by solvent/solvent partitioning, column chromatography and HPLC. Their structures were assigned on the basis of extensive 1D and 2D NMR studies as well as analysis by HRESIMS. Oppositines A (1) and B (2) showed moderate cytotoxicity against HCT116 cell lines with $\mathrm{EC}_{50}$ values of $27 \pm 2$ and $26 \pm 3 \mu \mathrm{M}$, respectively.
\end{abstract}

Poly-acetylated sesquiterpene pyridine alkaloids are ubiquitously found in the Celastraceae family of plants. ${ }^{1-4}$ Dihydro- $\beta$-agarofuran sesquiterpenes frequently incorporate pyridine dicarboxylic acids to bridge their sesquiterpenoid cores at the C-3 and C-13 positions. The dihydro- $\beta$-agarofuran skeleton is comprised of a decalin ring, a tetrahydrofuran ring, and methyl substituents located at the $\mathrm{C}-4, \mathrm{C}-10$, and two at the $\mathrm{C}-11$ position. Evoninic, wilfordic, edulic, cathaic, and cassininic (often misnamed cassinic) acids are some of the pyridine carboxylic acids present in this class of sesquiterpenes. These compounds are of interest due to their wide range of biological activities including: cytotoxicity, ${ }^{1}$ immunosuppression, ${ }^{2}$ insecticidal, $3,5,6$ insect-antifeedant, ${ }^{5,7}$ anti-HIV,${ }^{4}$ reversal of the multidrug resistance (MDR) phenotype,${ }^{8-11}$ and antitumor. ${ }^{12}$ As part of an ongoing search for bioactive compounds, two new sesquiterpene alkaloids, oppositines A (1) and B (2), were isolated from the Sri Lankan plant, Pleurostylia opposita (Wallich, 1824) (Celastraceae).

The air dried stem bark of $P$. opposita was extracted with 1:1 $\mathrm{MeOH} / \mathrm{CH}_{2} \mathrm{Cl}_{2}$. The extract was dried and partitioned between petroleum ether and aqueous $\mathrm{MeOH}$, and the aqueous $\mathrm{MeOH}$ was subsequently partitioned with chloroform. The chloroform-soluble material was fractionated using size exclusion chromatography, preparative TLC, and reversed-phase HPLC resulting in oppositines A (1) and B (2).

Oppositine A (1) was obtained as a light-yellow glass. The molecular formula, $\mathrm{C}_{44} \mathrm{H}_{51} \mathrm{NO}_{18}$, was determined by HRESIMS. Initial interpretation of the ${ }^{1} \mathrm{H}$ and ${ }^{13} \mathrm{C}$ NMR data indicated that 1 contained five acetyls and one hydroxyl. The data also indicated that oppositine A (1) contained four quaternary carbons, eight methines, five methylenes, and three methyls. The existence of a benzoate was suggested by the signals at $\delta_{\mathrm{H}} 7.80(\mathrm{dd}, J=7.9,1.3 \mathrm{~Hz}, \mathrm{H}-18$, $\left.\mathrm{H}-18^{\prime}\right), 7.52$ (tt, $\left.J=7.9,1.3 \mathrm{~Hz}, \mathrm{H}-20\right), 7.38$ (t, $\left.J=7.9 \mathrm{~Hz}, \mathrm{H}-19, \mathrm{H}-19^{\prime}\right)$, as well as five carbons at $\delta 164.6$ (C-16), 133.5 (C-20), 129.5 (C-18, C-18'), 129.1 (C-17), and 128.5 (C-19, C-19'). The signal at $\delta_{\mathrm{C}} 164.6(\mathrm{C}-16)$ was assigned to the carbonyl carbon of the benzoate based on

\footnotetext{
*To whom correspondence should be addressed. Tel: (801) 581-8305. Fax: (801) 585-6208. E-mail: cireland@ pharm.utah.edu.

†University of Utah

†university of Colombo
} 
an HMBC correlation with the proton signal at $\delta_{\mathrm{H}} 7.80\left(\mathrm{H}-18, \mathrm{H}-18^{\prime}\right)$. HSQC and HMBC data further supported the assignment of the benzoate group (Supplemental Table 1). The existence of a 2,3-disubstituted pyridine unit was suggested by the signals for three aromatic protons at $\delta_{\mathrm{H}} 8.82(\mathrm{dd}, J=4.6,1.9 \mathrm{~Hz}, \mathrm{H}-6), 8.39(\mathrm{dd}, J=8.0,1.9 \mathrm{~Hz}, \mathrm{H}-4), 7.26(\mathrm{dd}, J=8.0,4.6 \mathrm{~Hz}$, $\mathrm{H}-5$ ), as well as five aromatic carbons at $\delta_{\mathrm{C}} 168.1$ (C-2 ), 153.8 (C-6 ), 138.2 (C-4 ), 124.9 (C-3 ), and 120.8 (C-5 ). HSQC and HMBC data further supported the assignment of the 2,3disubstituted pyridine unit (Supplemental Table 1). A dicarboxy side chain containing two esters, one methine, two methylenes, one ethyl group, and the 2,3-disubstituted pyridine unit supported the presence of a cassininic acid moiety in oppositine A (1). The NMR data for this portion of the molecule are consistent with data reported for the analogous protons in the compounds cassinine ${ }^{13}$ and orthophosphonine. ${ }^{14}$ Based on COSY data, signals at $\delta_{\mathrm{H}} 5.88$, 5.22, and 5.01 were assigned to $\mathrm{H}-1, \mathrm{H}-2$, and $\mathrm{H}-3$, respectively, and signals at $\delta_{\mathrm{H}} 7.00,2.32$, 5.51 , and 5.38 were assigned to $\mathrm{H}-6, \mathrm{H}-7, \mathrm{H}-8$, and $\mathrm{H}-9$, respectively. Taken together, these data indicate that $\mathbf{1}$ is a sesquiterpene pyridine alkaloid with a dihydro- $\beta$-agarofuran skeleton. Oppositines A (1) and B (2) have been drawn with the tetrahydrofuran ring on the top face of the molecule so as to conform to the depiction of other cassininic acid containing molecules. 13,14 The tetrahydrofuran ring can also be drawn on the bottom side of the molecule, as is noted in a review of Celastraceae sesquiterpenoids. 15

The regiosubstitution of the various groups around the terpene skeleton was established based on HMBC data. In the HMBC spectrum of 1, the methyl singlets at $\delta_{\mathrm{H}} 2.31(\mathrm{H}-30), 2.19(\mathrm{H}-24)$, 2.10 (H-26), 1.38 (H-28), and 2.13 (H-22) correlated with the five acetyl carbonyl carbons at $\delta_{\mathrm{C}} 170.4(\mathrm{C}-29), 170.0$ (C-23), 170.0 (C-25), 168.9 (C-27), and 168.4 (C-21), respectively. An anisotropic effect caused by the benzoate at the $\mathrm{C}-1$ position is thought to be the cause of $\mathrm{H}-28$ resonating at such high field. The effect on $\mathrm{H}-28$ is observed in similar compounds with a benzoate at the $\mathrm{C}-1$ position. ${ }^{1,3,4}$ The attachment of the acetyl groups at C-2, C-6, C-8, C-9, and $\mathrm{C}-15$ was established based on $\mathrm{HMBC}$ correlations from the proton signals at $\delta_{\mathrm{H}} 5.22$ $(\mathrm{H}-2), 7.00(\mathrm{H}-6), 5.51(\mathrm{H}-8), 5.38(\mathrm{H}-9)$, and 4.63 (H-15b) to the acetyl carbonyls at $\delta_{\mathrm{C}} 168.4$ (C-21), 170.0 (C-23), 170.0 (C-25), 168.9 (C-27), and 170.4 (C-29), respectively. The attachment of the benzoate at $\mathrm{C}-1$ was supported by an $\mathrm{HMBC}$ correlation from the proton signal at $\delta_{\mathrm{H}} 5.88(\mathrm{H}-1)$ to the carbonyl signal at $\delta_{\mathrm{C}} 164.6(\mathrm{C}-16)$. The attachment of a methyl and a hydroxyl at $\mathrm{C}-4$ was established on the basis of $\mathrm{HMBC}$ correlations between $\delta_{\mathrm{H}} 1.56$ $(\mathrm{H}-14)$ and $\delta_{\mathrm{C}} 70.0(\mathrm{C}-4)$, as well as $\delta_{\mathrm{H}} 4.96(\mathrm{OH}-4)$ and $\delta_{\mathrm{C}} 70.0(\mathrm{C}-4)$. Additionally, HMBC correlations between the proton signals at $\delta_{\mathrm{H}} 5.01(\mathrm{H}-3)$ and 5.96, $3.59(\mathrm{H}-13 \mathrm{a}, \mathrm{H}-13 \mathrm{~b})$ and the carbon signals at $\delta_{\mathrm{C}} 172.2(\mathrm{C}-12)$ and $166.4(\mathrm{C}-13)$, respectively, supported the attachment of the cassininate moiety at C-3 and C-13. Sesquiterpene pyridine alkaloids characteristically include diastereotopic methylenes attached to $\mathrm{C}-13$ that resonate at very different chemical shifts. ${ }^{1-4}$

The relative stereochemistry of oppositine A (1), as shown in Figure 1, was established on the basis of coupling constants, observed ROE correlations, and molecular modeling. A ROESY experiment showing ROE effects for $\mathrm{H}-1$ to $\mathrm{H}-2, \mathrm{H}-9$, and $\mathrm{H}-12$; $\mathrm{H}-14$ to $\mathrm{H}-3, \mathrm{H}-6$, and $\mathrm{H}-15$; and $\mathrm{H}-9$ to $\mathrm{H}-8$, and $\mathrm{H}-12$, established the relative position of the substituent groups. All coupling constants associated with the terpene skeleton were less than $6 \mathrm{~Hz}$ (Supplemental Table 1), and supported the arrangements determined by the ROESY data. Therefore, the relative configuration in 1 was established as $1 R^{*}, 2 R^{*}, 3 S^{*}, 4 S^{*}, 5 S^{*}, 6 R^{*}, 7 R^{*}, 8 R^{*}, 9 S^{*}$, $10 R^{*}, 11 S^{*}$. The stereochemistry at $7^{\prime}$ was not determined.

Oppositine B (2) was obtained as a light-yellow glass. The molecular formula, $\mathrm{C}_{44} \mathrm{H}_{51} \mathrm{NO}_{17}$, was determined by HRESIMS, and suggested that oppositine B (2) had one less oxygen than oppositine A (1). Comparison of the NMR data of $\mathbf{2}$ with $\mathbf{1}$ confirmed the absence of the hydroxyl at the C-4 position. Specifically, a methine signal at $\delta_{\mathrm{H}} 2.72(\mathrm{H}-4)$, coupled to a methyl signal at $\delta_{\mathrm{H}} 1.24(\mathrm{H}-14)$, showed HMBC correlations to carbons at $\delta_{\mathrm{C}} 90.7(\mathrm{C}-5), 74.9$ 
(C-3), 70.4 (C-2), and 50.9 (C-10). The relative stereochemistry of 2 was established on the basis of coupling constants, observed ROE correlations, and comparison with 1 . A ROESY experiment showing ROE effects for H-1 to H-2, and H-9; H-14 to H-3, H-6, and H-15; and $\mathrm{H}-9$ to $\mathrm{H}-8$, and H-12, established the relative position of the substituent groups. All coupling constants were less than $6 \mathrm{~Hz}$ (Supplemental Table 1), and supported the arrangements determined from the ROESY data. Therefore, the relative configuration in $\mathbf{2}$ was established as $1 R^{*}, 2 S^{*}, 3 R^{*}, 4 R^{*}, 5 S^{*}, 6 R^{*}, 7 R^{*}, 8 R^{*}, 9 S^{*}, 10 R^{*}, 11 S^{*}$. The stereochemistry at $7^{\prime}$ was not determined.

Oppositines A (1) and B (2) showed moderate cytotoxicity against HCT116 cell lines with $\mathrm{EC}_{50}$ values of $27 \pm 2$ and $26 \pm 3 \mu \mathrm{M}$, respectively. Oppositines A (1) and B (2) were also tested for anti-HIV activity and HIF-1 $\alpha$ inhibition, but were inactive up to a concentration of $10 \mu \mathrm{g} / \mathrm{mL}$ in both assays. Antifungal activity assays for oppositines A (1) and B (2) are currently in progress.

To date only two cassininic acid metabolites have been reported, cassinine ${ }^{13}$ and orthophosphonine. ${ }^{14}$ Oppositine A (1) differs from cassinine in hydroxylation at the C-4 carbon and the position of the benzoate at the $\mathrm{C}-1$ carbon rather than the $\mathrm{C}-6$ carbon. Oppositine B (2) differs from cassinine in the position of the benzoate. Previous investigations of $P$. opposita have yielded lupane and spermidine derivatives. ${ }^{16-18}$ This is the first reported incidence of dihydro- $\beta$-agarofuran sesquiterpenes from $P$. opposita, although a plethora of such compounds has been reported from the Celastraceae family.

\section{Experimental Section}

\section{General Experimental Procedures}

Optical rotations were measured on a JASCO DIP-370 digital polarimeter. UV spectra were acquired in spectroscopy grade $\mathrm{MeOH}$ using a Hewlett Packard 8452A diode array spectrophotometer. IR spectra were recorded on a JASCO FT/IR-420 spectrometer. NMR spectra were recorded on a Varian INOVA spectrometer operating at $500 \mathrm{MHz}$ and $125 \mathrm{MHz}$, for ${ }^{1} \mathrm{H}$ and ${ }^{13} \mathrm{C}$, respectively. Chemical shifts are reported in ppm and were referenced to residual solvent. High-resolution ESIMS analyses were performed on either a ThermoFinnigan LTQ-FT or a Micromass Q-tof micro. Initial purification was performed on Sephadex LH-20 and HPTLC-Platten-Sil 60, Merck. HPLC was performed on a Beckman System Gold (diode array detector).

\section{Plant Material}

Stem bark of Pleurostylia opposita (Wallich, 1824) (Celastraceae) was obtained from a tree growing on the University of Colombo Campus, Sri Lanka, in July 2005, and was identified by Professor A.S. Seneviratne. A voucher specimen of the sample is on file at the Department of Plant Sciences, University of Colombo, Sri Lanka.

\section{Extraction and Isolation}

The stem bark (155 g) was air dried and soaked in $\mathrm{MeOH}-\mathrm{CH}_{2} \mathrm{Cl}_{2}(1: 1 \mathrm{v} / \mathrm{v})$. The crude extract was concentrated to dryness in vacuo and redissolved in a solution of $\mathrm{MeOH} / \mathrm{H}_{2} \mathrm{O}(9: 1)$. The aqueous $\mathrm{MeOH}$ solution was extracted with petroleum ether, then diluted with water to a composition of $\mathrm{MeOH} / \mathrm{H}_{2} \mathrm{O}(6: 4)$, and finally extracted with $\mathrm{CHCl}_{3}$. The $\mathrm{CHCl}_{3}$ soluble material was chromatographed on Sephadex LH-20 using EtOAc/MeOH/ $\mathrm{H}_{2} \mathrm{O}$ (40:10:4). The first of the two fractions collected was subjected to preparative TLC on silica gel using hexane/ EtOAc (2:8). The third of the four fractions obtained (UV visualization) was purified using a $\mathrm{C}_{18}$ monolithic column employing a gradient of $10 \% \mathrm{CH}_{3} \mathrm{CN} / \mathrm{H}_{2} \mathrm{O}$ to $50 \% \mathrm{CH}_{3} \mathrm{CN} / \mathrm{H}_{2} \mathrm{O}$ over 
$2 \mathrm{~h}$ and resulted in oppositine A $(\mathbf{1}, 3.5 \mathrm{mg}, 0.002 \%)$ eluting at $98.9 \mathrm{~min}$ and oppositine B (2, $1.5 \mathrm{mg}, 0.001 \%$ ) eluting at $107.3 \mathrm{~min}$.

Oppositine A (1): light yellow glass, $[\alpha]^{26}{ }_{\mathrm{D}}+20.3(c 0.13, \mathrm{MeOH}) ; \mathrm{UV}(\mathrm{MeOH}) \lambda_{\max }(\log$ ع) 270 (3.47) 230 (4.14) 206 (4.08) nm; IR (film) $v_{\max } 3453$ (br), 2961, 1744, 1584, 1451, $1369,1247,1156,1097,757,713 \mathrm{~cm}^{-1} ;{ }_{1}^{1} \mathrm{H} \mathrm{NMR}\left(\mathrm{CDCl}_{3}, 500 \mathrm{MHz}\right) \delta 8.82(1 \mathrm{H}, \mathrm{dd}, J=4.6$, $\left.1.9 \mathrm{~Hz}, \mathrm{H}-6^{\prime}\right), \delta 8.39\left(1 \mathrm{H}, \mathrm{dd}, J=8.0,1.9 \mathrm{~Hz}, \mathrm{H}-4^{\prime}\right), 7.80\left(2 \mathrm{H}, \mathrm{dd}, J=7.9,1.3 \mathrm{~Hz}, \mathrm{H}-18, \mathrm{H}-18^{\prime}\right)$, $7.52(1 \mathrm{H}, \mathrm{tt}, J=7.9,1.3 \mathrm{~Hz}, \mathrm{H}-20), 7.38\left(2 \mathrm{H}, \mathrm{t}, J=7.9 \mathrm{~Hz}, \mathrm{H}-19, \mathrm{H}-19^{\prime}\right), 7.26(1 \mathrm{H}, \mathrm{dd}, J=$ 8.0, 4.6 Hz, H-5'), $7.00(1 \mathrm{H}$, br s, H-6), $5.96(1 \mathrm{H}, \mathrm{d}, J=11.9 \mathrm{~Hz}, \mathrm{H}-13 \mathrm{a}), 5.88(1 \mathrm{H}, \mathrm{d}, J=4.1$ $\mathrm{Hz}, \mathrm{H}-1), 5.51(1 \mathrm{H}, \mathrm{dd}, J=5.8,4.1 \mathrm{~Hz}, \mathrm{H}-8), 5.38(1 \mathrm{H}, \mathrm{d}, J=5.8 \mathrm{~Hz}, \mathrm{H}-9), \delta 5.35(1 \mathrm{H}, \mathrm{d}, J=$ $13.5 \mathrm{~Hz}, \mathrm{H}-15 \mathrm{a}), 5.22(1 \mathrm{H}, \mathrm{dd}, J=4.1,2.4 \mathrm{~Hz}, \mathrm{H}-2), 5.01(1 \mathrm{H}, \mathrm{d}, J=2.4 \mathrm{~Hz}, \mathrm{H}-3), 4.96(1 \mathrm{H}$, br d, $J=1.4 \mathrm{~Hz}, \mathrm{OH}-4), 4.63(1 \mathrm{H}, \mathrm{d}, J=13.5 \mathrm{~Hz}, \mathrm{H}-15 \mathrm{~b}), 4.32$ (1H, dddd, $J=11.7,9.5,4.9$, $\left.2.7 \mathrm{~Hz}, \mathrm{H}-7^{\prime}\right), 3.59(1 \mathrm{H}, \mathrm{d}, J=11.9 \mathrm{~Hz}, \mathrm{H}-13 \mathrm{~b}), 2.32(1 \mathrm{H}, \mathrm{d}, J=4.1 \mathrm{~Hz}, \mathrm{H}-7), 2.31(3 \mathrm{H}, \mathrm{s}$, H-30), 2.26 (2H, m, H-10a', H-11a'), $\delta 2.19$ (3H, s, H-24), 2.13 (3H, s, H-22), 2.10 (3H, s, H-26), 1.98 (1H, ddd, $\left.J=13.1,7.4,2.7 \mathrm{~Hz}, \mathrm{H}-8 \mathrm{a}^{\prime}\right), 1.87\left(2 \mathrm{H}, \mathrm{m}, \mathrm{H}-10 \mathrm{~b}^{\prime}, \mathrm{H}-11 \mathrm{~b}^{\prime}\right), 1.72(1 \mathrm{H}$, $\mathrm{m}, J=7.4 \mathrm{~Hz}, \mathrm{H}-8 \mathrm{~b}$ '), 1.71 (3H, s, H-12), 1.56 (3H, br d, $J=1.4 \mathrm{~Hz}, \mathrm{H}-14), 1.38$ (3H, s, H-28), $0.68\left(3 \mathrm{H}, \mathrm{t}, J=7.4, \mathrm{H}-9^{\prime}\right) ;{ }^{13} \mathrm{C} \mathrm{NMR}\left(\mathrm{CDCl}_{3}, 125 \mathrm{MHz}\right) \delta 172.2\left(\mathrm{C}-12^{\prime}\right), 170.4(\mathrm{C}-29), 170.0$ (C-23, C-25), 168.9 (C-27), 168.4 (C-21), 168.1 (C-2'), 166.4 (C-13'), 164.6 (C-16), 153.8 (C-6'), 138.2 (C-4'), 133.5 (C-20), 129.5 (C-18, C-18'), 129.1 (C-17), 128.5 (C-19, C-19'), 124.9 (C-3'), 120.8 (C-5'), 94.0 (C-5), 85.0 (C-11), 75.7 (C-3), 73.7 (C-6), 73.5 (C-1), 71.4 (C-9), 70.0 (C-2, C-4), 69.8 (C-13), 68.9 (C-8), 60.1 (C-15), 52.5 (C-10), 50.8 (C-7), 42.2 (C-7'), 31.8 (C-10'), 31.3 (C-11'), 28.8 (C-8'), 22.9 (C-14), 21.6 (C-24), 21.4 (C-30), 21.0 (C-26), 20.9 (C-22), 19.9 (C-28), 18.0 (C-12), 11.9 (C-9) ) HRESIMS m/z 882.3183 [M + $\mathrm{H}]^{+'}$ (calcd for $\mathrm{C}_{44} \mathrm{H}_{52} \mathrm{NO}_{18}, 882.3184$ ).

Oppositine B (2): light yellow glass, $[\alpha]^{26} \mathrm{D}+19.5(c 0.07, \mathrm{MeOH}) ; \mathrm{UV}(\mathrm{MeOH}) \lambda_{\max }(\log$ ع) 268 (3.68) 228 (4.35) 204 (4.27) nm; IR (film) $v_{\max }$ 2928, 1744, 1567, 1451, 1369, 1226, $1157,1074,757,713 \mathrm{~cm}^{-1} ;{ }^{1} \mathrm{H}$ NMR $\left(\mathrm{CDCl}_{3}, 500 \mathrm{MHz}\right) \delta 8.78\left(1 \mathrm{H}, \mathrm{br} \mathrm{d}, J=3.9 \mathrm{~Hz}, \mathrm{H}-6^{\prime}\right)$, $8.20\left(1 \mathrm{H}\right.$, br d, $\left.J=6.8 \mathrm{~Hz}, \mathrm{H}-4^{\prime}\right), 7.85\left(2 \mathrm{H}\right.$, br d, $\left.J=7.7 \mathrm{~Hz}, \mathrm{H}-18, \mathrm{H}-18^{\prime}\right), 7.53(1 \mathrm{H}$, br t, $J=$ $7.7 \mathrm{~Hz}, \mathrm{H}-20), 7.39$ (2H, br t, $\left.J=7.7 \mathrm{~Hz}, \mathrm{H}-19, \mathrm{H}-19^{\prime}\right), 7.24\left(1 \mathrm{H}, \mathrm{dd}, J=6.8,3.9 \mathrm{~Hz}, \mathrm{H}-5^{\prime}\right)$, $6.65(1 \mathrm{H}, \mathrm{br} \mathrm{s}, \mathrm{H}-6), 6.00(1 \mathrm{H}, \mathrm{d}, J=4.0 \mathrm{~Hz}, \mathrm{H}-1), 5.67(1 \mathrm{H}, \mathrm{d}, J=11.3 \mathrm{~Hz}, \mathrm{H}-13 \mathrm{a}), 5.53(1 \mathrm{H}$, dd, $J=5.9,3.8 \mathrm{~Hz}, \mathrm{H}-8), 5.37(1 \mathrm{H}, \mathrm{d}, J=5.9 \mathrm{~Hz}, \mathrm{H}-9), 5.33(1 \mathrm{H}, \mathrm{br} \mathrm{d}, J=4.0 \mathrm{~Hz}, \mathrm{H}-2), 5.28$ $(1 \mathrm{H}, \mathrm{d}, J=13.2 \mathrm{~Hz}, \mathrm{H}-15 \mathrm{a}), 4.83(1 \mathrm{H}, \mathrm{br} \mathrm{s}, \mathrm{H}-3), 4.63(1 \mathrm{H}, \mathrm{d}, J=13.2 \mathrm{~Hz}, \mathrm{H}-15 \mathrm{~b}), 4.00(1 \mathrm{H}$, m, H-7'), $3.59(1 \mathrm{H}, \mathrm{d}, J=11.3 \mathrm{~Hz}, \mathrm{H}-13 \mathrm{~b}), 2.72(1 \mathrm{H}, \mathrm{q}, J=7.9 \mathrm{~Hz}, \mathrm{H}-4), 2.41(1 \mathrm{H}, \mathrm{d}, J=3.8$ Hz, H-7), 2.23 (3H, s, H-30), 2.23 (1H, m, H-11a'), 2.21 (3H, s, H-24), 2.20 (1H, m, H-10a'), $2.12(3 \mathrm{H}, \mathrm{s}, \mathrm{H}-26), 2.09$ (3H, s, H-22), 1.98 (1H, m, J = 7.2, H-8a'), 1.87 (1H, m, H-10b'), 1.80 $\left(1 \mathrm{H}, \mathrm{m}, \mathrm{H}-11 \mathrm{~b}^{\prime}\right), 1.79\left(1 \mathrm{H}, \mathrm{m}, J=7.2 \mathrm{~Hz}, \mathrm{H}-8 \mathrm{~b}^{\prime}\right), 1.65$ (3H, s, H-12), 1.42 (3H, s, H-28), 1.24 $(3 \mathrm{H}, \mathrm{d}, J=7.9 \mathrm{~Hz}, \mathrm{H}-14), 0.76\left(3 \mathrm{H}, \mathrm{t}, J=7.2, \mathrm{H}-9^{\prime}\right) ;{ }^{13} \mathrm{C} \mathrm{NMR}\left(\mathrm{CDCl}_{3}, 125 \mathrm{MHz}\right) \delta 172.8$ (C-12'), 170.2 (C-29), 170.0 (C-25), 169.7 (C-23), 168.9 (C-27), 168.7 (C-21), 165.5 (C-13'), 165.4 (C-2'), 164.7 (C-16), 152.6 (C-6'), 138.0 (C-4'), 133.4 (C-20), 129.5 (C-18, C-18'), 129.3 (C-17), 128.5 (C-19, C-19'), 127.4 (C-3'), 120.9 (C-5'), 90.7 (C-5), 82.9 (C-11), 74.9 (C-3), 74.2 (C-6), 74.0 (C-1), 71.5 (C-9), 70.4 (C-2), 69.0 (C-8), 68.8 (C-13), 60.2 (C-15), 50.9 (C-10), 50.2 (C-7), 42.1 (C-7'), 36.9 (C-4), 30.7 (C-11'), 30.3 (C-10'), 29.0 (C-8'), 21.6 (C-24), 21.4 (C-30), 21.1 (C-26), 20.9 (C-22), 19.9 (C-28), 18.1 (C-12), 14.9 (C-14), 12.0 (C-9'); HRESIMS $\mathrm{m} / z 888.3087[\mathrm{M}+\mathrm{Na}]^{+}$(calcd for $\mathrm{C}_{44} \mathrm{H}_{51} \mathrm{NO}_{17} \mathrm{Na}, 888.3055$ ).

\section{Cell culture and MTT assay. 19}

The cancer cell line HCT-116 (human colon tumor) was grown at $37^{\circ} \mathrm{C}, 5 \% \mathrm{CO}_{2}$ in $\mathrm{McCoy}$ 's 5a medium containing $10 \%$ fetal bovine serum, penicillin $(50 \mathrm{IU} / \mathrm{mL})$, streptomycin $(50 \mu \mathrm{g} /$ $\mathrm{mL}$ ) and $2 \mathrm{mM} \mathrm{L}$-glutamine. Cells were plated at a density of 5000 cells/well in a 96-well plate. Twenty-four hours after plating, the cells were exposed to medium containing the compound at a concentration of $0.03 \mu \mathrm{M}$ to $100 \mu \mathrm{M}$ for $48 \mathrm{~h}$ at $37^{\circ} \mathrm{C}$. After the cells were exposed to the 
compound, $100 \mu \mathrm{L}$ of fresh culture medium containing MTT at a final concentration of 0.3 $\mathrm{mg} / \mathrm{mL}$ were added to each well and incubated for $3 \mathrm{~h}$ at $37^{\circ} \mathrm{C}$. The absorbance of each well was measured by a microplate reader (Multi-skan labsystems) at $570 \mathrm{~nm}$. The percentage cytotoxicity was calculated by comparison of the $A_{570}$ reading from treated versus control cells.

\section{Supplementary Material}

Refer to Web version on PubMed Central for supplementary material.

\section{Acknowledgements}

The authors wish to acknowledge Dr. P. Krishna and Dr. C. Nelson, University of Utah Mass Spectrometry and Proteomics Core Facility, for performing some of the LRESIMS and HRESIMS experiments. Funding for the Varian INOVA $500 \mathrm{MHz}$ NMR spectrometer was provided through NIH Grant RR06262. This work was supported by NIH grant CA36622 (C.M.I.).

\section{References and Notes}

1. Kuo YH, King ML, Chen CF, Chen HY, Chen CH, Chen K, Lee KH. J Nat Prod 1994;57:263-269. [PubMed: 8176403]

2. Duan H, Takaishi Y, Momota H, Ohmoto Y, Taki T, Jia Y, Li D. J Nat Prod 2001;64:582-587. [PubMed: 11374948]

3. Nunez MJ, Guadano A, Jimenez IA, Ravelo AG, Gonzalez-Coloma A, Bazzocchi IL. J Nat Prod 2004;67:14-18. [PubMed: 14738378]

4. Duan H, Takaishi Y, Imakura Y, Jia Y, Li D, Cosentino LM, Lee KH. J Nat Prod 2000;63:357-361. [PubMed: 10757718]

5. Gonzalez AG, Jimenez IA, Ravelo AG, Coll J, Gonzalez JA, Lloria J. Biochem Syst Ecol 1997;25:513519.

6. Wu W, Wang M, Zhu J, Zhou W, Hu Z, Ji Z. J Nat Prod 2001;64:364-367. [PubMed: 11277758]

7. Liu JK, Jia ZJ, Wu DG, Zhou J, Wang QG. Phytochemistry 1990;29:2503-2506.

8. Perez-Victoria JM, Tincusi BM, Jimenez IA, Bazzocchi IL, Gupta MP, Castanys S, Gamarro F, Ravelo AG. J Med Chem 1999;42:4388-4393. [PubMed: 10543882]

9. Kim SE, Kim YH, Lee JJ, Kim YC. J Nat Prod 1998;61:108-111. [PubMed: 9461657]

10. Kennedy ML, Cortes-Selva F, Perez-Victoria JM, Jimenez IA, Gonzalez AG, Munoz OM, Gamarro F, Castanys S, Ravelo AG. J Med Chem 2001;44:4668-4676. [PubMed: 11741484]

11. Munoz-Martinez F, Lu P, Cortes-Selva F, Perez-Victoria JM, Jimenez IA, Ravelo AG, Sharom FJ, Gamarro F, Castanys S. Cancer Res 2004;64:7130-7138. [PubMed: 15466210]

12. Gonzalez AG, Tincusi BM, Bazzocchi IL, Tokuda H, Nishino H, Konoshima T, Jimenez IA, Ravelo AG. Bioorg Med Chem 2000;8:1773-1778. [PubMed: 10976526]

13. Wagner H, Bruning R, Lotter H, Jones A. Tetrahedron Lett 1977;18:125-128.

14. Gonzalez AG, Andres LS, Ravelo AG, Luis JG, Jimenez IA, Dominguez XA. J Nat Prod 1989;52:1338-1341.

15. Spivey AC, Weston M, Woodhead S. Chem Soc Rev 2002;31:43-59. [PubMed: 12108982]

16. Seguineau C, Richomme P, Bruneton J, Meadows P. Heterocycles 1994;38:181-187.

17. Seguineau C, Richomme P, Bruneton J, Pusset J. Helv Chim Acta 1992;75:2283-2288.

18. Dantanarayana AP, Kumar NS, Sultanbawa MUS, Balasubramaniam S. J Chem Soc, Perkin Trans 1 1981:2717-2723.

19. Mosmann T. J Immunol Methods 1983;65:55-63. [PubMed: 6606682] 

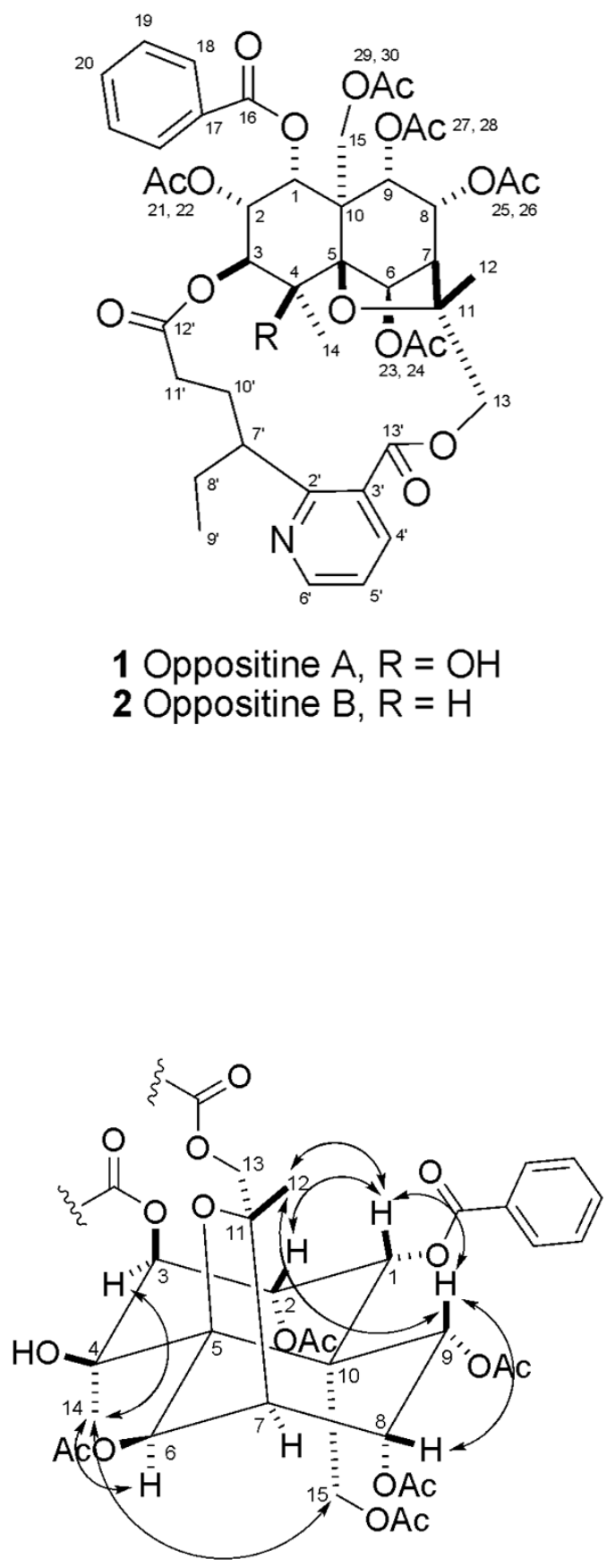

Figure 1.

Key ROE correlations supporting the relative stereochemistry of oppositine A (1). 